\title{
Cattle drinking water quality in the cow-calf beef operation in southern Chihuahua, Mexico
}

\section{Calidad del agua de consumo animal en el sistema vaca-cría del sur de Chihuahua, México}

\author{
Rubén Alfonso Saucedo-Terán ${ }^{1} *$, Celia Holguín-Licón ${ }^{2}$, Pedro Jurado-Guerra ${ }^{1}$, Jesús Manuel Ochoa-Rivero ${ }^{1}$, \\ Héctor Osbaldo Rubio-Arias ${ }^{2}$ \\ ${ }^{1}$ Sitio Experimental La Campana. Instituto Nacional de Investigaciones Forestales, Agrícolas y Pecuarias. Km 33.3 carretera \\ Chihuahua-Ojinaga. CP. 32910. Aldama, Chihuahua, México \\ ${ }^{2}$ Facultad de Zootecnia y Ecología. Universidad Autónoma de Chihuahua. Periférico Francisco R. Almada, Km 1. CP. 31000. \\ Chihuahua, Chihuahua. México \\ *Autor de correspondencia: rasteran@yahoo.com.mx
}

Artículo científico recibido: 20 de abril de 2016, aceptado: 12 de noviembre de 2017

\begin{abstract}
Despite the key role of water in livestock growth and reproduction, there is little information on water quality for Mexico's beef cattle ranches. The objective of this study was to evaluate drinking water quality for beef cattle in the cow-calf operation through calculation of a water quality index (WQI) that relates water physical-chemical composition with common cattle drinking water sources. The study was conducted in 25 cattle ranches of the cow-calf system in seven municipalities of Chihuahua, Mexico. In all cattle ranches, water samples were collected from the main water sources, and physical and chemical parameters were analyzed. Statistical analyses were done through Kruskal-Wallis test, considering water sources (WS) as a source of variation. The WQI was calculated considering the parameters closely related to animal health and productivity and following standard procedures. Most parameters showed high variation among WS. The only parameters influenced by WS were $\mathrm{pH}$, As $(\mathrm{p}<0.05)$ and $\mathrm{Co}(\mathrm{p}<0.01)$. The parameters that surpassed the optimum level for cattle drinking were turbidity for all WS and Mn for earthen tank and spring/river water. Groundwater showed the best quality with a 50.34 WQI, corresponding to good class. Earthen tank water also corresponded to good class with a 98.8 WQI, while spring/river water was classified as poor water for cattle with a 114.47 WQI.
\end{abstract}

Key words: Beef cattle, earthen tanks, groundwater, river, spring

RESUMEN. Existe poca información sobre la calidad del agua en los ranchos ganaderos de México. El objetivo fue evaluar la calidad del agua que bebe el ganado mediante el cálculo de un índice de calidad de agua (ICA) que relaciona su composición físico-química con los tipos de abrevaderos tradicionales. El estudio se llevó a cabo en 25 ranchos del sistema vaca-cría de siete municipios del estado de Chihuahua. En cada rancho se tomaron muestras de agua para determinar su composición físico-química. Los datos obtenidos fueron sometidos a una prueba de Kruskal-Wallis, considerando los tipos de abrevadero (TA) como factor de estudio. EI ICA fue calculado con base en los parámetros relacionados con la salud y productividad del ganado y siguiendo procedimientos estandarizados. La mayoría de los parámetros mostraron una alta variabilidad con respecto a TA. Los únicos parámetros que se vieron influenciados por TA fueron $\mathrm{pH}$ y As $(\mathrm{p}<0.05)$ y Co $(\mathrm{p}<0.01)$. Los parámetros que sobrepasaron los niveles óptimos para consumo animal fueron la turbidez en todos los TA y el Mn en presones y manantiales y/o ríos. El agua de pozo mostró la mejor calidad con un ICA de 50.34 el cual corresponde a una calificación de buena. El agua de presones también obtuvo una calificación de buena con un ICA de 98.8. El agua de manantial y/o río fue calificada como pobre con un ICA de 114.47.

Palabras clave: Agua de pozo, ganado bovino de carne, manantial, presones, río 


\section{INTRODUCTION}

Water is the main body constituent of animals and a basic component in the functioning and maintenance of their physiological processes. It represents up to $74 \%$ of soft tissue and participates in their vital processes (Speakman et al. 2001). Water is fundamental in saliva production for food mastication and swallowing, waste secretion, body temperature regulation, tissue lubrication, milk production, mineral balance, $\mathrm{pH}$ maintenance, and nervous system buffering (Mississippi State University 2008). As part of animal feeding, water is the simplest nutrient but the highest in volume for any given animal. Animals can withstand long periods of time without food, but they can only withstand a few days without water. Therefore, water availability in both quantity and quality not only represents a productivity factor, but also a sign of respect for animals and their rights to have a healthy and comfortable (Lardner et al. 2005).

Water quality in cattle ranches is influenced by natural and anthropogenic factors and can be internal and external. Internal factors can be geomorphology, range type and condition, water sources, cattle management, and rusting of machinery and facilities (Fava et al. 2002). In shrub-lands, dominant soils are sedimentary and calcareous, so water may be alkaline with high salt content and metals such as aluminum. Conversely, soils in grasslands are volcanic, alluvial, neutral or lightly acid, and low in salts (COTECOCA 1978). In terms of plant cover, there is an inverse relationship between basal cover and soil erosion by water (Havstad et al. 2007, Quiñones-Vera et al. 2009), which means higher soil particles and salts on stock-water developments such as streams, rivers, tanks, and dams (Holguín et al. 2006). Water quality is also closely related to cattle management. It is common that cattle go into ponds and dams when drinking, causing sediment movement and water contamination by cattle urine and manure (Sherer et al. 1988). Conversely, this rarely happens when using water troughs (Surber et al. 2003). In relation to external factors, water at cattle ranches can be affected by anthropogenic activities that potentially generate contaminants including urban wastes, minemetallurgic, and agriculture activities (Korenekova et al. 2002, Lukowski and Water 2011).

Despite the key role of water in livestock growth and reproduction, there is little information on water quality, not only for cattle ranches but also for any livestock enterprise. No research was found on water quality for cattle ranches under extensive conditions in north Mexico. This might be relevant since cattle ranches receive water runoff from urban sources and other potential contaminating sources like mining and agriculture. These anthropogenic activities represent potential contamination for animal water sources. However, it is unknown whether water runoff has an effect on water quality of groundwater, tanks, springs and rivers that flow through cattle ranches. The objective of this study was to evaluate drinking water quality for beef cattle in the cow-calf operation through calculation of a water quality index that relates water physical-chemical composition with common drinking water sources of cattle ranches in southern Chihuahua, Mexico.

\section{MATERIALS AND METHODS}

The study was carried out at 25 cattle ranches of the cow-calf system located in seven municipalities of Chihuahua, Mexico. Orography of the ranches varies from valleys to hills and low mountains. Climate of this region is dry temperate, with temperatures ranging from $-12^{\circ} \mathrm{C}$ to $32^{\circ} \mathrm{C}$, and mean annual precipitation of $450 \mathrm{~mm}$. Vegetation varies from grasslands and shrub-lands in the valleys to woodlands in the mountains, including several tree and tree-like species such as pine (Pinus spp), Juniperus deppeana and oak (Quercus spp). Main vegetation types where cattle ranches are located include mesquite (Prosopis glandulosa) shrubland, creosotebush (Larrea tridentata) shrubland, oakbunchgrass, and shortgrass prairie (COTECOCA 1978). Anthropogenic activities representing potential for water contamination in cattle ranches take place in all studied municipalities. Mining activities 
are the most common in Hidalgo del Parral, Santa Barbara, and San Francisco del Oro municipalities, with gold, silver, lead, copper, zinc, fluorite, and barite mining. Also, irrigated agriculture in Allende, Coronado, and Matamoros, and forestry in San Francisco del Oro and Huejotitan municipalities are important economic activities (INEGI 2009 a,b).

In all cattle ranches, water sources for cattle were identified and samples were collected to determine their quality based on their physical and chemical variables, metals and metalloids. The water sources were groundwater, earthen tank and springriver. A total of 43 water samples, $1.0 \mathrm{~L}$ each, were taken in plastic bottles. In each ranch, a sample of each available water source was taken. From the 43 samples, 28 came from groundwater and nine from earthen tanks (eight from non-fenced tanks where cattle got into the water, and one from a fenced earthen tank). The other six water samples came from permanent streams (four from springs and two from low flow rivers). Water samples from groundwater were taken at water troughs. The earthen tank water samples were taken from the water body's edge. In the water springs and rivers, water samples were taken directly from the sites where cattle regularly drink water. None of the water springs or rivers were fenced, so cattle got into water for drinking, with possible contamination of water by soil erosion, runoff, and cattle urine and feces. Water samples were collected from march to april 2011, during the dry season. Proximity of ranches to potential contamination sources was also recorded. Two ranches were close $(<5 \mathrm{~km})$ to wastewater sources, four close to mining wastes $(<5 \mathrm{~km})$, one close to irrigated crops, two close to dry-land crops, and the rest were far ( $>5 \mathrm{~km})$ from potential contamination sources. After collection, water samples were placed in an ice-chest and transported to laboratory and kept refrigerated at $4^{\circ} \mathrm{C}$ until physical and chemical analysis. Water sampling and management were performed under Mexican regulations (SECOFI 1980).

Estimated parameters were potential of hydrogen $(\mathrm{pH})$, electrical conductivity $(\mathrm{EC})$, dissolved oxygen (DO), turbidity (TUR), total suspended solids (TSS), total dissolved solids (TDS), metals and metalloids (As, Cd, Co, Cr, Cu, Mg, Mn, Ni, $\mathrm{Pb}, \mathrm{Se}$, and $\mathrm{Zn}$ ). Potential of hydrogen and $\mathrm{EC}$ were estimated with a Hanna Instruments ${ }^{\circledR}$ model HI-98130 multiparametric tester (SE 2011, SECOFI 2000). DO was estimated through SE (2001a). A $60 \mathrm{ml}$ aliquot was placed in a covered recipient, and 5 drops of $A$ reactive and five drops of $B$ reactive were added; the recipient was closed, stirred and left to stand until sedimentation of the material, which took about $2 \mathrm{~min}$. Then, 10 drops of reactive $C$ were added to the recipient, covered and stirred again. When the sample turned to light yellow, DO concentration was measured in a Hanna Instruments ${ }^{\circledR}$ model HI-9146 oximeter. To estimate TUR, a Hanna Instruments ${ }^{\circledR}$ model H193703 turbidity meter (SE 2001b) was used. Solid contents (TS, TSS, and TDS) were estimated according to the Mexican regulation (SE 2015). Total solids were analyzed through dehydration $\left(110^{\circ} \mathrm{C}\right.$ for $\left.24 \mathrm{~h}\right)$ of a $50 \mathrm{ml}$ aliquot in a porcelain bowl, and weighted by difference at ambient temperature. Total dissolved solids were estimated according to the SE (2015) method, using a $50 \mathrm{ml}$ aliquot passed through a vacuum pump with a filter in a Buchner funnel. Once the filtration process ended, filter paper was placed in a stove at $60^{\circ} \mathrm{C}$ for $24 \mathrm{~h}$. After that, filter paper was dried at ambient temperature, and weighed. Total dissolved solids were calculated by weight difference between TS and TSS. Metal and metalloids were quantified using the SE (2001c) Mexican regulation. Digestion process was performed with a $100 \mathrm{ml}$ aliquot and $5 \mathrm{ml}$ of nitric acid until completion. Then, the digested aliquot was filtered and tri-distilled water added up to the original volume. Concentration of metals and metalloids was done with an ICP Optical Emission Spectrophotometer (Perkin Elmer ${ }^{R}$ model 8300). Data were analyzed with Kruskall-Wallis non-parametric test, since data did not comply with normality assumption required for parametric tests (Bautista et al. 2009). $\mathrm{Pb}, \mathrm{Mn}, \mathrm{Cu}$ and $\mathrm{Cd}$ were excluded from this analysis, because of heteroscedasticity. The oneway Kruskall-Wallis test was performed (SAS 2008) with water source as source of variation. 
Water quality index (WQI) was determined considering the parameters closely related to animal health and productivity, according to Alobaidy et al. (2010), and constructed in five steps:

A specific weight $(\mathrm{Wi})$ on a 1 to 4 scale was given to the selected parameters, based on their importance as water quality indicators for cattle. A value of one was given to less important parameters and four to more important parameters (Table 1 ). Values of Wi correspond to standard values reported from research articles and obtained from experts through panel sessions (Wright 2007, Olkowski 2009, Almeida et al. 2012, Gharibi et al. 2012, Curran 2014).

Relative weight of each parameter was estimated through the following equation:

$$
P_{i}=\frac{W_{i}}{\sum_{i=1}^{n}} W_{i}
$$

Where: $P_{i}=$ Relative weight of each parameter, $W_{i}=$ Specific weight of each parameter (1-4), $n=$ Number of parameters (1-n).

Quality rating was calculated through the following equation:

$$
q_{i}=\frac{C_{i}}{O_{i}} X 100
$$

Where: $q_{i}=$ Quality Rating, $C_{i}=$ Chemical concentration of each parameter, $O_{i}=$ Optimum value for each parameter (Table 2).

Values of Oi were assigned based on several reports (Carson 2000, CCME 2005, SEDUE1989, FAO 1994, Higgins et al. 2008).

The water sub-quality index ( $\mathrm{Si}$ ) was obtained for each parameter:

$$
S_{i}=p_{i} \times q_{i}
$$

The water quality index (WQI) was estimated through the summation of the Si for each parameter:

$$
W Q I=\sum_{n}^{i=1} S_{i}
$$

The WQI obtained for each water source was qualified based on the classification proposed by Sahu and Sikdar (2008). According to them, a WQI less than 50 corresponds to excellent quality water; a WQI from 50 to 100 to good water; a WQI from 100 to 200 to poor water; a WQI from 200 to 300 to very poor water and a WQI above 300 to water unsuitable for drinking.

\section{RESULTS}

Values for $W i$ assigned to the studied variables are shown at Table 1 . Arsenic, $\mathrm{Cd}, \mathrm{Cr}$, $\mathrm{Ni}$, and $\mathrm{Pb}$ received a value of 4 since they have a high impact on cattle health and productivity. Four variables (EC, TUR, TSS, TDS, and Co) were assigned a value of 3 . Copper, $\mathrm{Mg}$, and $\mathrm{Mn}$ received a value of 2 , and finally, Se and $Z n$ received a value of 1 because of their low importance as cattle water quality indicators.

Table 3 shows physical and chemical composition of drinking water for cattle in the study area. The only parameters influenced by water source were $\mathrm{pH}, \mathrm{As}(\mathrm{p}<0.05)$ and $\mathrm{Co}(\mathrm{p}<0.01)$. The rest of the means are only different in descriptive terms. Highest $\mathrm{pH}$ value corresponded to groundwater and earthen tank water with 7.9, and decreased to 7.3 in spring/river water. Values for As and Co showed that both parameters were higher in earthen tank than in groundwater and spring/river water sources. Mean values for EC were from 322 in earthen tank to $509 \mu \mathrm{S} \mathrm{cm}{ }^{-2}$ in groundwater. Groundwater showed lower TUR with 16.9 NTU compared to the other water sources, and always was higher than the range and optimum limits for all water sources. However, in our study, TSS were similar and varied from $166 \mathrm{mg} \mathrm{L}^{-1}$ in groundwater to $128 \mathrm{mg} \mathrm{L}^{-1}$ in spring/river water. TDS values were $417.7,504.4$ and $643.3 \mathrm{mg} \mathrm{L}^{-1}$ for river/spring, groundwater and earthen tank, respectively, and were within range and optimum lim- 
Saucedo-Terán et al.

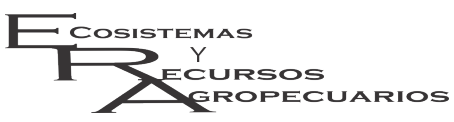

Beef cattle drinking water quality

Ecosist. Recur. Agropec.

4(11):331-340,2017

Table 1. Values of $W_{i}$ and cattle health and performance implications of the parameters used to determine $W Q I$ in northern Mexico's cow-calf system.

\begin{tabular}{|c|c|c|c|}
\hline Parameter & Units & $W_{i}$ & Implications \\
\hline $\mathrm{pH}$ & - & * & Alteration of cattle water intake, health, and performance. \\
\hline EC & $\mu \mathrm{S} \mathrm{cm}^{-1}$ & 3 & Alteration of cattle health. \\
\hline TUR & NTU & 3 & Alteration of water intake. \\
\hline TSS & $\mathrm{mg} \mathrm{L^{-1 }}$ & 3 & Alteration of cattle water intake, health, and performance. \\
\hline TDS & $\mathrm{mg} \mathrm{L}^{-1}$ & 3 & Alteration of cattle water intake, health, and performance. \\
\hline DO & $\mathrm{mg} \mathrm{L}^{-1}$ & * & Low concentrations indicate toxic contaminants ( $\mathrm{NO} 3, \mathrm{NH} 3$ and $\mathrm{PO} 4)$. \\
\hline As & $\mathrm{mg} \mathrm{L}^{-1}$ & 4 & Toxicity. \\
\hline $\mathrm{Cd}$ & $\mathrm{mg} \mathrm{L}^{-1}$ & 4 & Toxicity. \\
\hline Co & $\mathrm{mg} \mathrm{L}^{-1}$ & 3 & Alteration of cattle health, occasionally toxic. \\
\hline $\mathrm{Cr}$ & $\mathrm{mg} \mathrm{L}^{-1}$ & 4 & Toxicity. \\
\hline $\mathrm{Cu}$ & $\mathrm{mg} \mathrm{L}-1$ & 2 & Alteration of cattle health, occasionally toxic. \\
\hline $\mathrm{Mg}$ & $\mathrm{mg} \mathrm{L}^{-1}$ & 2 & Alteration of cattle health, occasionally toxic. \\
\hline $\mathrm{Mn}$ & $\mathrm{mg} \mathrm{L}^{-1}$ & 2 & Alteration of cattle health. \\
\hline $\mathrm{Ni}$ & $\mathrm{mg} \mathrm{L}^{-1}$ & 4 & Toxicity. \\
\hline $\mathrm{Pb}$ & $\mathrm{mg} \mathrm{L}^{-1}$ & 4 & Toxicity. \\
\hline Se & $\mathrm{mg} \mathrm{L}^{-1}$ & 1 & Alteration of cattle health, occasionally toxic. \\
\hline Zn & $\mathrm{mg} \mathrm{L}^{-1}$ & 1 & Alteration of cattle health, occasionally toxic. \\
\hline
\end{tabular}

Table 2. Permissible maximum/minimum limits, optimum range and optimum value $\left(O_{i}\right)$ of the physical and chemical variables, heavy metals and metalloids for beef cattle drinking water according to different references.

\begin{tabular}{lccccccc}
\hline \multicolumn{7}{c}{ Permissible maximum $/$ minimum limits } \\
\hline Parameter & $\begin{array}{c}\text { Higgins } \\
\text { et al., }(2008)\end{array}$ & $\begin{array}{c}\text { SEDUE } \\
(1989)\end{array}$ & $\begin{array}{c}\text { Carson } \\
(2000)\end{array}$ & $\begin{array}{c}\text { CCME } \\
(2005)\end{array}$ & $\begin{array}{c}\text { FAO } \\
(1994)\end{array}$ & $\begin{array}{c}\text { Optimum } \\
\text { range }\end{array}$ & $\begin{array}{c}\text { Optimum } \\
\text { value }\left(O_{i}\right)\end{array}$ \\
\hline $\mathrm{pH}^{*}$ & $5-9$ & - & - & $6-9$ & $6-8$ & $6-9$ & 7.5 \\
$\mathrm{EC}$ & - & - & - & $<1500$ & $<1500$ & $500-1500$ & 1000 \\
$\mathrm{TUR}$ & - & - & - & - & - & $3-4$ & 3.5 \\
$\mathrm{TSS}$ & $1000-3000$ & - & - & - & - & $1000-3000$ & 2000 \\
$\mathrm{TDS}$ & $1000-3000$ & 1000 & - & - & 3000 & $1000-3000$ & 2000 \\
$\mathrm{DO} *$ & - & 6 & - & - & - & $6-8$ & 7 \\
$\mathrm{As}$ & 0.2 & 0.2 & 0.2 & 0.2 & 0.025 & $0-0.2$ & 0.1 \\
$\mathrm{Cd}$ & 0.05 & 0.02 & 0.05 & 0.05 & 0.08 & $0.02-0.08$ & 0.05 \\
$\mathrm{Co}$ & 0.5 & - & 1 & 1 & 1 & $0.5-1$ & 0.75 \\
$\mathrm{Cr}$ & 1 & - & 1 & 1 & 0.05 & $0.05-1$ & 0.5 \\
$\mathrm{Cu}$ & 0.5 & 0.5 & 0.5 & 0.5 & 0.5 & 0.5 & 0.5 \\
$\mathrm{Mg}$ & - & - & - & 400 & - & 400 & 400 \\
$\mathrm{Mn}$ & 0.5 & - & - & 0.05 & - & 0.05 & 0.05 \\
$\mathrm{Ni}$ & - & - & - & 1 & 1 & 1 & 0.5 \\
$\mathrm{~Pb}$ & 0.1 & - & 0.1 & 0.1 & 0.1 & 0.1 & 0.05 \\
$\mathrm{Se}$ & 0.05 & - & 0.05 & 0.05 & 0.05 & 0.05 & 0.05 \\
$\mathrm{Zn}$ & 24 & - & 25 & 24 & 50 & $24-50$ & 37 \\
\hline
\end{tabular}

its. Concentration of DO was similar among water sources, varying from 7.5 to $7.9 \mathrm{mg} \mathrm{L}^{-1}$. Metal and metalloid concentration fell within optimum range, except $\mathrm{Mn}$ for earthen tank and spring/river waters ( 0.45 and $0.85 \mathrm{mg} \mathrm{L}^{-1}$, respectively) that exceeded range and optimum values.

As shown in Table 3, groundwater showed best quality with a 50.34 WQI, corresponding to good class. Earthen tank water also corresponded to good class with a $98.8 \mathrm{WQI}$, while spring/river water was classified as poor water for cattle with a 114.47 WQI. Those parameters that surpassed optimum level for cattle drinking were TUR for all water sources and $\mathrm{Mn}$ for earthen tank and spring/river waters. None of high importance $\left(W_{i}=4\right)$ parameters had higher concentrations than optimum.

\section{DISCUSSION}

Methodology used for WQI estimation is de- 
Saucedo-Terán et al.

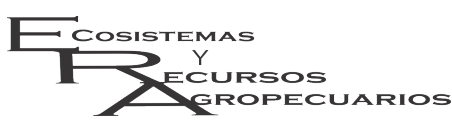

Beef cattle drinking water quality

Ecosist. Recur. Agropec.

4(11):331-340,2017

Table 3. Water physical and chemical parameters (mean $\pm \mathrm{SE}$ ) and $W Q I$ values in northern Mexico's cattle cow-calf operation according to water source.

\begin{tabular}{|c|c|c|c|c|}
\hline \multicolumn{5}{|c|}{ Water Source } \\
\hline Parameter & Units & $\begin{array}{r}\text { Groundwater } \\
(n=28)\end{array}$ & $\begin{array}{r}\text { Earthen Tank } \\
(n=9)\end{array}$ & $\begin{array}{r}\text { Spring/River } \\
(n=6)\end{array}$ \\
\hline $\mathrm{pH} *$ & & $7.9 \pm 0.1$ & $7.9 \pm 0.2$ & $7.3 \pm 0.1$ \\
\hline EC & $\mu \mathrm{S} \mathrm{cm-2}$ & $509 \pm 135$ & $322 \pm 85$ & $403 \pm 101$ \\
\hline TUR & NTU & $16.9 \pm 3.1$ & $26.6 \pm 7.5$ & $26.5 \pm 8.4$ \\
\hline TSS & mg L-1 & $165.8 \pm 14.3$ & $139.6 \pm 25.3$ & $127.7 \pm 39.7$ \\
\hline TDS & $\mathrm{mg} \mathrm{L}-1$ & $504.4 \pm 145.4$ & $643.3 \pm 367.8$ & $417.7 \pm 117.6$ \\
\hline DO * & mg L-1 & $7.9 \pm 0.2$ & $7.5 \pm 0.5$ & $7.9 \pm 0.5$ \\
\hline As & mg L-1 & $0.012 \pm 0.003$ & $0.023 \pm 0.006$ & $0.012 \pm 0.002$ \\
\hline $\mathrm{Cd}$ & $\mathrm{mg} \mathrm{L}-1$ & $0.002 \pm 0.001$ & $0.007 \pm 0.007$ & $0.001 \pm 0.001$ \\
\hline Co & $\mathrm{mg} \mathrm{L}-1$ & $0.002 \pm 0.001$ & $0.01 \pm 0.006$ & $0.002 \pm 0.001$ \\
\hline $\mathrm{Cr}$ & mg L-1 & $0.104 \pm 0.012$ & $0.113 \pm 0.023$ & $0.123 \pm 0.029$ \\
\hline $\mathrm{Cu}$ & mg L-1 & $0.025 \pm 0.004$ & $0.045 \pm 0.019$ & $0.028 \pm 0.01$ \\
\hline $\mathrm{Mg}$ & $\mathrm{mg} \mathrm{L}-1$ & $7.6 \pm 1.3$ & $6.2 \pm 1.5$ & $11.1 \pm 2.3$ \\
\hline $\mathrm{Mn}$ & $\mathrm{mg} \mathrm{L}-1$ & $0.015 \pm 0.003$ & $0.45 \pm 0.201$ & $0.85 \pm 0.828$ \\
\hline $\mathrm{Ni}$ & mg L-1 & $0.097 \pm 0.024$ & $0.136 \pm 0.066$ & $0.216 \pm 0.13$ \\
\hline $\mathrm{Pb}$ & $\mathrm{mg} \mathrm{L}-1$ & $0.006 \pm 0.001$ & $0.023 \pm 0.009$ & $0.006 \pm 0.002$ \\
\hline Se & mg L-1 & $0.006 \pm 0.001$ & $0.008 \pm 0.006$ & $0.01 \pm 0.004$ \\
\hline $\mathrm{Zn}$ & mg L-1 & $0.151 \pm 0.036$ & $0.17 \pm 0.07$ & $0.159 \pm 0.086$ \\
\hline WQI & - & 50.34 & 98.8 & 114.47 \\
\hline
\end{tabular}

signed for those parameters whose beneficial effect on water quality is inversely related to their concentration (Alobaidy et al. 2010). Therefore, in the calculation of WQI, DO was not included because this parameter follows a direct relationship to water quality. Similarly, $\mathrm{pH}$ was not included since this variable affects water quality under both low and high values. In terms of permissible limits, $\mathrm{pH}$ values in the three water sources were within the optimum range (6-9) and only spring/river water was slightly below optimum value of 7.5 (Table 2 ). Values for $\mathrm{pH}$ in our study are similar to those of Brew et al. (2011) who mentioned that water $\mathrm{pH}$ varies with water source within the same ranch, from 7.0 in groundwater to 7.4 in earthen tank water. The EC values obtained in our study are similar to those found by Banoeng-Yakubo et al. (2009) and fall within range and optimum value specifications. According to Mukhtar et al. (2009), EC is an indicator of dissolved salts in water and is a common problem in arid regions. Probably, these low EC values may be explained by the fact that most of the ranches $(15 / 25)$ are not confined to arid regions. Main toxic effects of EC include abdominal pain, nasal and nervous disorders (Curran 2014).
TUR is an indicator of water cleanness and may be correlated to TSS, depending on the kind of water source (Almeida et al. 2012). In groundwater, an important factor for TUR increasing is algae presence (Rasby and Waltz 2011), although wind may generate dust, increasing TUR and TSS. TSS values were higher than those reported in other studies (Surber et al. 2003) but did not exceed the range and optimum values for cattle drinking water. Sherer et al. (1988) mentioned that water TSS concentration increases when cattle get into water to drink. TSS generate from runoff during intense rain in soils with low plant cover (Havstad et al. 2007, Quiñones-Vera et al. 2009, Hone-Jay et al. 2013). TDS values were similar among water sources. TDS concentration varies naturally with salt runoff from soil that goes into surface water. In the case of groundwater, TDS is directly affected by hydrogeochemical properties of the aquifers (Thivya et al. 2014, Mosley 2015). Domestic waste water discharge and cattle mismanagement contribute to the increase of TDS in surface water (Surber et al. 2003, Rajankar et al. 2011). Although Mn showed a higher than optimum concentration in earthen tanks and spring/river sources, cattle in- 
toxication by this metal in water is rare. High intake of $\mathrm{Mn}$ causes anemia and digestive disorders (Olkowski 2009). Sources of $\mathrm{Mn}$ in water are natural soil-borne, cattle feed, and waste water from urban centers (Sommers 1977, Blanco-Penedo et al. 2009).

Results of WQI obtained in this study are similar to other studies where the same methodology was used (Banoeng-Yakubo et al. 2009, Alobaidy et al. 2010, Gharibi et al. 2012, Thivya et al. 2014). These authors reported that the most influencing parameters in the WQI were heavy metals and TDS concentration. Differences in water sources observed in this study concur with other investigations. In a study made in Oregon, Miner et al. (1992) determined that cattle prefer groundwater offered in a water trough rather than spring/river or earthen tank water. Similarly, yearling steers drinking groundwater gained $23 \%$ more weight than those drinking earthen tank water in Alberta, Canada, due to a higher TSS concentration in earthen tank water (Surber et al. 2003).

\section{CONCLUSIONS}

Cattle drinking water in the cow-calf system in southern Chihuahua, Mexico is good for groundwater and earthen tank, and poor for spring/rivers. Water quality parameters that negatively influenced $W Q I$ were turbidity and Manganese concentration. To obtain reliable data about the effects of water on animal health, it would be necessary to include other diagnostic variables, in addition to the water quality indicators used in this study.

\section{LITERATURE CITED}

Almeida C, González SO, Mallea M, González P (2012) A recreational water quality index using chemical, physical and microbiological parameters. Environmental Science and Pollution Research 19: 3400-3411.

Alobaidy AHMJ, Haider A, Bahram M (2010) Application of water quality index for assessment of Dokan Lake Ecosystem, Kurdistan Region, Iraq. Journal of Water Resources Protection 2: 792-798.

Banoeng-Yakubo B, Yidana SM, Emmanuel N, Akabzaa T, Asiedu D (2009) Analysis of groundwater quality using water quality index and conventional graphical methods: the Volta region, Ghana. Environmental Earth Science 59: 867-879.

Bautista MN, Soto RL, Pérez PR (2009) Tópicos selectos de estadística aplicada a la fitosanidad. Colegio de Posgraduados, Texcoco, Estado de México, México. 256p.

Blanco-Penedo I, Shore RF, Miranda M, Benedito JL, López-Alonso M (2009) Factors affecting trace element status in calves in NW Spain. Livestock Science 123: 198-208.

Brew MN, Carter J, Maddox MK (2011) The Impact of water quality on beef cattle health and performance. AN187. University of Florida. Florida, USA. 4p.

Carson TL (2000) Current knowledge of water quality and safety for livestock. Veterinary Clinics of North America. Food Animal Practice 16: 455-464.

CCME (2005) Canadian Council of Ministers of the Environment. Canadian water quality guidelines for the protection of agricultural water uses. In: Canadian environmental quality guidelines, 1999, Canadian Council of Ministers of the Environment, Winnipeg. http://www.ccme.ca/en/resources/canadian_envi ronmental_quality_guidelines/. Date consulted: april 20, 2014.

COTECOCA (1978) Comisión Técnica Consultiva para la determinación de los coeficientes de agostadero. Coeficientes de agostadero del estado de Chihuahua. SARH. Chihuahua, México. 149p. 
Curran G (2014) Water for livestock: interpreting water quality tests. NSW Government. Primefact 533. (2nd ed.). http://www.dpi.nsw.gov.au/__data/assets/pdf_file/0018/111348/water-for-livestock-in terpreting-water-quality-tests.pdf. Date consulted: april 4, 2014.

FAO (1994) Food and Agriculture Organization of the United Nations. Water quality for agriculture. http://www.fao.org/DOCReP/003/T0234e/T0234E00.htm. Data consulted: august 14, 2014.

Fava G, Fratesi R, Ruello ML, Sani D (2002) Soil zinc contamination from corrosion of galvanized structures. Chemistry Ecology 18: 223-232.

Gharibi H, Sowlat MH, Mahvia AH, Mahmoudzadeh H, Arabalibeik H, Keshavarz M, et al. (2012) Development of a dairy cattle drinking water quality index (DCWQI) based on fuzzy inference systems. Ecological Indicators 20: 228-239.

Havstad KM, Peters D, Skaggs R, Brown J, Bestelmeyer B, Fredrickson E, et al. (2007) Ecological services to and from rangelands of the United States. Ecological Economics 64: 261-268.

Higgins SF, Agouridis CT, Gumbert AA (2008) Drinking water quality guidelines for cattle. http://www2.ca. uky.edu/agc/pubs/id/id170/id170.pdf. Date consulted: april 4, 2014.

Holguín C, Rubio H, Olave ME, Saucedo R, Gutiérrez M, Bautista R (2006) Calidad del agua del río Conchos en la región de Ojinaga, Chihuahua: Parámetros fisicoquímicos, metales y metaloides. Universidad y Ciencia 22: 51-63.

Hone-Jay C, Chun-Yu L, Chi-Kuei W (2013) Identifying the relationships between water quality and land cover changes in the Tseng-Wen tank watershed of Taiwan. International Journal of Environmental Research and Public Health 10: 478-489.

INEGI (2009a) Instituto Nacional de Estadística y Geografía. Prontuario de información geográfica municipal de los Estados Unidos Mexicanos Santa Bárbara, Chihuahua. http://www3.inegi.org.mx/sistemas/mexi cocifras/datosgeograficos/08/08060.pdf. Date consulted: february 3, 2015.

INEGI (2009b) Instituto Nacional de Estadística y Geografía. Prontuario de información geográfica municipal de los Estados Unidos Mexicanos Hidalgo del Parral, Chihuahua. http://www3.inegi.org.mx/sistemas/ mexicocifras/datos-geograficos/08/08032.pdf. Date consulted: february 3, 2015.

Korenekova B, Skalicka M, Nad P (2002) Concentration of some heavy metals in cattle reared in the vicinity of a metallurgic industry. Veterinarski Arhiv 72: 259-267.

Lardner HA, Kirychuk BD, Braul L, Willms WD, Yarotski J (2005) The effect of water quality on cattle performance on pasture. Australian Journal of Agricultural Research 56: 97-104.

Lukowski A, Water J (2011) Influence of mineral fertilization on lead, cadmium, and chromium fraction contents in soil. Polish Journal of Environmental Studies 20: 951-960.

Miner JR, Buckhouse JC, Moore JA (1992) Evaluation of off-stream water source to reduce impact of winter fed range cattle on stream water quality. Oregon State University, Corvallis, OR. http://Ishs.tamu.edu/ docs/Ishs/end-notes/evaluation\%20of\%20off-stream\%20water\%20sour-2921446930/evaluation\%20of $\% 20$ off-stream $\% 20$ water $\% 20$ source $\% 20$ to $\% 20$ reduce $\% 20$ impact $\% 20$ of\%20winter $\% 20$ fed $\% 20$ range $\% 20$ cattle\%20on\%20stream\%20water\%20quality.pdf. Date consulted: january 23, 2014.

Mississippi State University (2008) Beef Cattle Water Requirements and Source Management. Publication 2490. http://msucares.com/pubs/publications/p2490.pdf. Date consulted: july 22, 2014.

Mosley LM (2015) Drought impacts on the water quality of freshwater systems; review and integration. Earth-Science Review 140: 203-214. 
Mukhtar S (2009) Water quality for livestock and poultry. New Mexico State University. Guide M-112. 2p. http://publications.tamu.edu/WATER/PUB_water_Water\%20Quality\%20Guide\%20for\%20Livestock \%20and\%20Poultry.pdf. Date consulted: april 4, $20 \overline{14}$.

Olkowski AA (2009) Livestock Water Quality. A field guide for cattle, horses, poultry, and swine. Agriculture and Agri-Food Canada, Ottawa, ON, Canada. 157p.

Quiñones-Vera JJ, Castellanos-Pérez CM, Martínez-Ríos JJ, Sánchez-Olvera CA (2009) Effect of biological soil crust on water infiltration in a rangeland. Terra Latinoamericana 27: 287-293.

Rajankar PN, Tambekar DH, Wate SR (2011) Groundwater quality and water quality index at Bhandara District. Environment Monitoring and Assessment 179: 619-625.

Rasby RJ, Waltz TM (2011) Water requirements for beef cattle. University of Nebraska - Lincoln Extension. Institute of Agriculture and Natural Resources. Nebraska, USA. 3p.

Sahu P, Sikdar PK (2008) Hydrochemical framework of the aquifer in and around East Kolkata wetlands, West Bengal, India. Environmental Geology 55: 823-835.

SAS (2008) SAS/STAT 9.2 User's Guide, SAS Institute Inc., Cary, North Carolina, USA.

SE (2001a) Secretaria de Economía. Norma Mexicana NMX-AA-012-SCFI-2001. Análisis de agua - Determinación de oxígeno disuelto en aguas naturales, aguas residuales y aguas residuales tratadas - Método de prueba.

SE (2001b) Secretaría de Economía. Norma Mexicana NMX-AA-038-SCFI-2001. Análisis de agua - Determinación de turbidez en aguas naturales, aguas residuales y aguas residuales tratadas - Método de prueba.

SE (2001c) Secretaría de Economía. Norma Mexicana NMX-AA-051-SCFI-2001. Análisis de agua - Determinación de metales por absorción atómica en aguas naturales, aguas residuales y aguas residuales tratadas - Método de prueba. http://www.agua.org.mx/biblioteca-tematica/marco-juridico-delagua/1466-normas-mexicanas/15242-nmx-aa-051-scfi-2001-analisis-de-agua-determinacion-de-metalespor-absorcion-atomica-en-aguas-naturales-potables-residuales-y-residuales-tratadas-metodo-de-prueba. Date consulted: may 9, 2016.

SE (2011) Secretaría de Economía. Norma Mexicana NMX-AA-008-SCFI11. Análisis de agua - Determinación de $\mathrm{pH}$ - Método de prueba. http://lasa.ciga.unam. $\mathrm{mx} / \mathrm{monitoreo/images/biblioteca/41 \% 20NMX-}$ AA-008-SCFI-2011_pH.pdf. Date consulted: December 9, 2016.

SE (2015) Secreatria de Economía. Norma Mexicana NMX-AA-034-SCFI-2015 (2015). Análisis de agua - Determinación de sales y sólidos disueltos en aguas naturales, aguas residuales y aguas residuales tratadas - Método de prueba.

SECOFI (1980) Secretaria de Comercio y Fomento Industrial. Norma Mexicana NMX-AA-014-SCFI-1980 Cuerpos receptores - Muestreo.

SECOFI (2000). Secretaria de Comercio y Fomento Industrial. Norma mexicana NMX-AA-093-SCFI-2000. Análisis de agua - Determinación de conductividad eléctrica - Método de prueba. http://lasa.ciga.unam. $\mathrm{mx} / \mathrm{monitoreo} /$ images/biblioteca/46\%20NMX-AA-093-SCFI-2000_Conductividad.pdf. Date consulted: april 9, 2016.

SEDUE (1989) Secretaría de Desarrollo Urbano y Ecología. Criterios Ecológicos de Calidad del Agua - CECCA-001/89. Diario Oficial de la Federación, 13 de diciembre de 1989. http://www.dof.gob.mx/nota detalle.php?codigo=4837548\&fecha=13/12/1989. Date consulted. april 10, 2016. 
Sherer BM, Miner JR, Moore JA, Buckhouse JC (1988) Resuspending organisms from a rangeland stream bottom. Transactions of the ASAE 31: 1217-1222.

Sommers LE (1977) Chemical composition of sewage sludges and analysis of their potential use as fertilizers. Journal of Environmental Quality 6: 225-232.

Speakman JR, Booles D, Butterwick R (2001) Validation of dual energy X-ray absorptiometry (DXA) by comparison with chemical analysis of dogs and cats. International Journal of Obesity 25: 439-447.

Surber G, Williams K, Manoukian M (2003) Drinking water quality for beef cattle: an environment friendly and production management enhancement technique, Montana State University, Natural resources information and publications. 4p. https://extension.usu.edu/rangelands/files/uploads/Water/Drinking\%20 Water\%20Quality.pdf. Data consulted: april 20, 2016.

Thivya C, Chidambaram S, Thilagavathi R, Nepolian M, Adithya VS (2014) Evaluation of drinking water quality index (DWQI) and its seasonal variations in hard rock aquifers of Madurai district, Tamilnadu. International Journal of Advanced Geosciences 2: 48-52.

Wright CL (2007) Management of water quality for beef cattle. Veterinary Clinics of North America: Food Animal Practice 23: 91-103. 